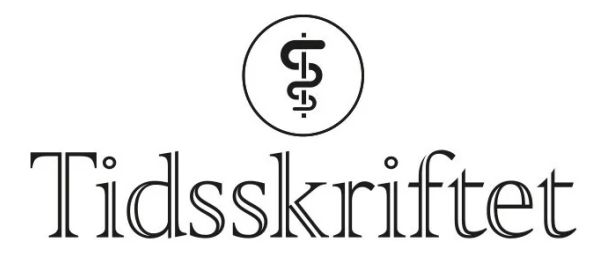

DEN NORSKE LEGEFORENING

\title{
Hyperkalemi, hjertesvikt og nedsatt nyrefunksjon
}

NOE Å LARE AV

JAN FREDRIK BUGGE

Email: jan.fredrik.bugge@oslo-universitetssykehus.no Akuttklinikken

Oslo universitetssykehus, Rikshospitalet

Postboks 4950 Nydalen

0424 Oslo

Moderne hjertesviktbehandling baserer seg i økende grad på kombinasjoner av medikamenter som blokkerer nevrohormonelle mekanismer. Disse består av betablokkere, angiotensinkonverterende enzym (ACE)-hemmere, angiotensin II- reseptor (AII)-blokkere, reninhemmere og aldosteronantagonister. Alle disse medikamentene kan bidra til utvikling av hyperkalemi. Betablokkere reduserer cellulært opptak av $\mathrm{K}^{+}$, mens ACEhemmere, AII-blokkere og reninhemmere, som alle er hemmere i renin-angiotensinsystemet, redusererer sekresjonen av aldosteron. I tillegg vil de i varierende grad kunne redusere glomerulær filtrasjonshastighet avhengig av i hvilken grad AII bidrar til å opprettholde aktuell hastighet. Aldosteronantagonister blokkerer aldosteronreseptorer i distale nyretubuli og hemmer dermed nefronets evne til å utskille kalium. Bortsett fra aldosteronantagonister bidrar medikamentene hver for seg ikke så mye til å øke nivået av $\mathrm{K}^{+}$i plasma, men ved kombinasjoner øker sannsynligheten for utvikling av hyperkalemi, og den øker mer jo flere medikamenter man kombinerer. Inntil nylig har man trodd at forekomst av alvorlig hyperkalemi var svært sjeldent, men med økende forskrivning av aldosteronantagonister som del av kombinasjonsterapien til pasienter med hjertesvikt har antall sykehusinnleggelser og dødsfall relatert til hyperkalemi økt, og det vekker bekymring (1).

Pasienter med hjertesvikt har ofte redusert nyrefunksjon med redusert renal blodgjennomstrømning og nedsatt glomerulær filtrasjonshastighet. Faktorer som disponerer for hjertesvikt slik som hypertensjon, diabetes, aldring og koronarsykdom, disponerer også for nyresvikt, og den vil ofte progrediere parallelt med hjertesvikten (므). Med økende nyresvikt øker også risikoen for å utvikle alvorlig hyperkalemi, og en forhøyet kreatininverdi er en betydelig risikofaktor for hyperkalemi ved bruk av blokkere og hemmere i renin-angiotensin-aldosteron-systemet (므). I de store kliniske studiene hvor nytten av disse medikamentene ble dokumentert, var høye kalium- og kreatininverdier eksklusjonskriterier (3). Det er imidlertid intet som tyder på at disse pasientgruppene har noe mindre nytte av behandlingen, snarere tvert imot, da de er mest utsatt for 
kardiovaskulære hendelser (4.). Det har ført til at forekomsten av alvorlig hyperkalemi i praksis er langt hyppigere enn i de kontrollerte, randomiserte studiene som ligger til grunn for behandlingsstrategien (3). For å begrense forekomsten av alvorlig hyperkalemi kreves risikovurdering hos den enkelte pasient, individuell dosering av medikamenter, rådgivning og oppmerksomhet omkring kosthold, interkurrente sykdommer og interaksjoner med andre medikamenter, samt nøye overvåking av laboratorieverdier.

I denne sammenhengen er det viktig å være oppmerksom på at gastroenteritter og andre lidelser som gir dehydrering, kan utløse akutt nyresvikt med livstruende hyperkalemi. Likeledes må man være oppmerksom på risikoen ved bruk av ikke-steroide antiflogistika (NSAID) inklusive COX-2-hemmere. Det er et komplisert samspill mellom renale prostaglandiner, renin-angiotensin-aldosteron-systemet, renal blodgjennomstrømning og glomerulær filtrasjonshastighet som jeg ikke skal komme inn på her, men mange av disse pasientene er avhengig av intakt prostaglandinsyntese for å opprettholde sin glomerulære filtrasjon. Hos disse vil hemming av prostaglandinsyntesen $\emptyset$ ke risikoen for hyperkalemi, og NSAID-preparater bør i størst mulig grad unngås til denne pasientgruppen.

Forekomsten av hjertesvikt i befolkningen $ø$ ker. Det har sammenheng med at antall eldre $\emptyset k e r$, og at moderne hjertesviktbehandling gjør at de lever lenger. Det betyr igjen at vi må forvente flere tilfeller av alvorlig hyperkalemi og flere sykehusinnleggelser hvor dette er en medvirkende årsak.

\section{Oppgitte interessekonflikter:}

Ingen

\section{LITTERATUR}

1. Juurlink DN, Mamdani MM, Lee DS et al. Rates of hyperkalemia after publication of the randomized aldactone evaluation study. N Engl J Med 2004; 351: 543-51.

2. Segura J, Ruilope LM. Hyperkalemia risk and treatment of heart failure. Heart Fail Clin 2008; 4: 45564.

3. Desai AS. Hyperkalemia in patients with heart failure: incidence, prevalence, and management. Curr Heart Fail Rep 2009; 6: 272-80.

4. Desai AS. Hyperkalemia associated with inhibitors of the renin-angiotensin- aldosterone system: balancing risk and benefit. Circulation 2008; 118:16o9-11.

Publisert: 1. juli 2010. Tidsskr Nor Legeforen. DOI: 10.4045/tidsskr.10.0463

Manuskriptet ble mottatt 19.4. 2010 og godkjent 6.5. 2010. Medisinsk redaktør Trine B. Haugen.

(C) Tidsskrift for Den norske legeforening 2023. Lastet ned fra tidsskriftet.no 26. april 2023. 